\title{
Analysis of feeding behaviour and gastro-somatic index (GaSI) during different phases of breeding cycle of Monopterus cuchia (Hamilton, 1822) from Meghalaya, India
}

\author{
Barisha Mary Kurbah \\ Assam Don Bosco University, Tapesia Gardens, Kamarkuchi, Sonapur-782402 (Assam), \\ India \\ Rabindra Nath Bhuyan* \\ Department of Fishery Science, St. Anthony's College, Shillong (Meghalaya), India \\ *Corresponding author. E-mail: rnbhuyan60@gmail.com
}

\section{Article Info}

DOI:10.31018/jans.v10i4.1907 Received: September 26, 2018 Revised: October 24, 2018

Accepted: November 8, 2018

\section{How to Cite}

Kurbah, B. M. and Bhuyan, R.N. (2018). Analysis of feeding behavior and gastro-somatic index (GaSI) during different phases of breeding cycle of Monopterus cuchia (hamilton, 1822) from Meghalaya, India. Journal of Applied and Natural Science, 10 (4): 1187 - 1191

Keywords: Feeding Intensity, GaSI, Maturity Stages, Monopterus cuchia, RLG

\section{INTRODUCTION}

Monopterus cuchia locally known as 'Khabsein' in Meghalaya is a species belonging to the family Synbranchidae of the order Synbranchiformes. It is available only in selected pockets of Meghalaya viz; Khweng and Nongpoh (Ri-Bhoi District), Shella (East-Khasi Hills District) and Baghmara (Garo Hills District) and it is an economically important freshwater fish, recorded from India, Nepal, Bangladesh, Pakistan and Myanmar (Menon, 1999; Mirza and Alam, 2002; Zhou et al., 2002). Mud Eel have also been reported as the species with high medicinal value and the fresh blood of cuchia is directly consumed to cure weakness, anemia and asthma (Jamir and Lal, 2005; Kakati et al., 2006). This species inhabits fresh and brackish waters (Talwar and Jhingran, 1991) and their casual existence are found during the drought season in mud holes (Menon, 1999). It is an obligatory airbreathing fish, which inhabits holes and crevices in the muddy banks of swamps, lakes, ponds and slow flowing rivers containing fresh and brackish water (Munshi et al., 1989). M. cuchia is nocturnal in nature and the fish is considered to be carnivorous by feeding habit which mostly prefers animal based food. They feed on earthworms, frogs, tadpoles, small aquatic animals, shrimp, crayfish and also on detritus (Narejo et al., 2003). With ecological importance and high nutritional components, this fish can play a unique role in culture fisheries for the development of socio-economic status of fishermen (Quddus et al., 2000).

Feeding is one of the most important functions of an organism in order to be healthy and productive. Basic functions such as growth, development, reproduction etc. all take place at the expense of the energy, which enters the organism in the form of its food. Feeding activity influences the growth and productivity of fishes. Feeding is the dominant activity of the entire life cycle of fish (Joadder and Hossain, 2008). The study of the food and feeding habit of fishes provide keys for the selection of culturable species and such information is necessary for successful fish farming (Manon and Hossain, 2011).

Several workers have reported the analysis of different aspects of feeding biology of various fish species at different level. However, no report was available regarding food and feeding habits of Mud Eel from Meghalaya. Hence, the present study was aimed at investigating the food and feeding habit of M.cuchia. The analysis of gut content, Gastro-Somatic Index (GaSI) and Relative Length of the Gut (RLG) will definitely help in achieving basic information on overall biology of this fish species.

\section{MATERIALS AND METHODS}

Monthly samples of Mud Eel ( $M$. cuchia) were brought from different areas of Meghalaya name- 
Kurbah, B. M. and Bhuyan, R.N. / J. Appl. \& Nat. Sci. 10 (4): 1187 - 1191 (2018)

Table 1. Showing Gastro-Somatic Index (GaSI), Relative Length of the Gut (RLG) and food habit of M. cuchia.

\begin{tabular}{|c|c|c|c|c|c|c|}
\hline Stages & $\begin{array}{l}\text { Degree of } \\
\text { maturity }\end{array}$ & $\begin{array}{l}\text { Months of } \\
\text { availability }\end{array}$ & $\begin{array}{l}\text { Number } \\
\text { of fish }\end{array}$ & $\begin{array}{l}\text { Gastro-Somatic } \\
\text { Index (GaSI) }\end{array}$ & $\begin{array}{l}\text { Relative Length } \\
\text { of the Gut (RLG) }\end{array}$ & Food habit \\
\hline $\mathrm{I}$ & Immature & (October-December) & 30 & 2.70 & 0.66 & Carnivorous \\
\hline II & Maturing & $\begin{array}{l}\text { Pre-Breeding } \\
\text { (January-February) }\end{array}$ & 30 & 3.14 & 0.72 & Carnivorous \\
\hline III & Mature & $\begin{array}{l}\text { Breeding } \\
\text { (March-June) }\end{array}$ & 30 & 2.13 & 0.75 & Carnivorous \\
\hline IV & Spent & $\begin{array}{l}\text { Post-Breeding } \\
\text { (July-September) }\end{array}$ & 30 & 2.56 & 0.70 & Carnivorous \\
\hline
\end{tabular}

Seasonal Variation of Gastro-Somatic Index (GSI) in M. cuchia

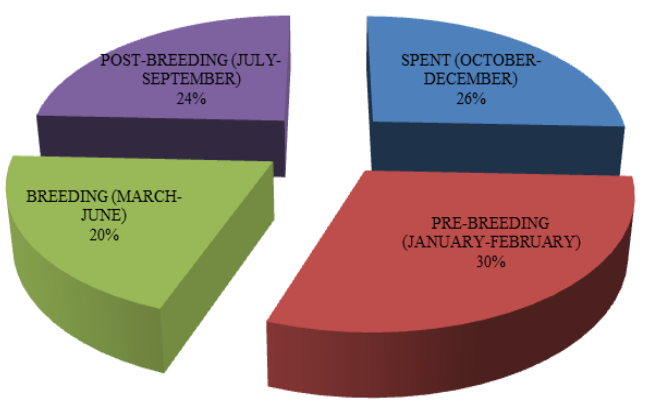

Fig. 1. Pie chart showing seasonal variation of GaSI in M.cuchia.

ly; Khweng and Nongpoh (Ri-Bhoi District), Shella (East Khasi Hills District) and Baghmara (Garo Hills District) during the month of January 2016February 2018. A total of 120 specimens were collected during the study period for analyzing certain aspects of feeding biology. After collection, specimens were carefully packed and brought to the Hatchery Complex; St. Anthony's College, Shillong and reared in specially managed cemented cisterns. Total length of each individual specimen was measured using a standard measuring scale and total weight was also measured using a Sartorius electronic balance. Guts of the specimens were carefully dissected out and total length and total weight of gut was also recorded. Gut content of the fishes was analyzed based on the method by (Nikolsky, 1963). Gastro-Somatic Index (GaSl) was also assessed as per (Bhatnagar and Karamchandani, 1970) method using the formula:

GaSI $=$ Total weight of gut contents $($ Food $) /$ Total wt. of fish $\times 100 \quad$................. 1 Moreover, the Relative length of the gut (RLG) was analyzed by (Al-Hussaini, 1949) method using the formula:

$\mathrm{RLG}=$ Total length of gut/ Total length of fish

..Eq.2

\section{RESULTS}

A total of one hundred and twenty (120) specimens were analyzed in this study. The gut content analysis of Monopterus cuchia was done and revealed that the insect larvae and zooplankton comprised the major part of their food items. Food items found in the gut content of $M$. cuchia mainly

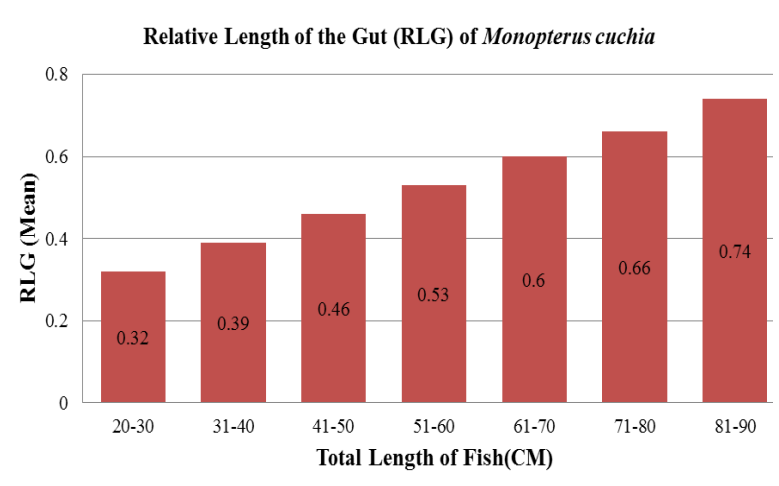

Fig. 2. Column chart showing the Relative Length of the Gut (RLG) of M. cuchia of different sizes.

includes the Annelids (such as the Earthworms, Sludge worms, Leeches etc), Copepods, Cladocerans (namely Bosmina, Sididae etc), Rotifera, Insect larvae, Insect body parts, Sand, Mud as well as some unidentified species. Due to the presence of noticeable amount of sand and mud in gut of this species, this suggested that $\mathrm{M}$. $\mathrm{Cu}$ chia is a bottom feeder. The results obtained for Gastro-Somatic Index (GaSI) and Relative Length of the gut (RLG) in different reproductive phases are shown in Table 1 ; and Figs. 1-2 respectively. From the experiment conducted, Gastro-Somatic Index (GaSI) value of 2.70 (October-December), 3.14 (January-February), 2.13 (March-June) and 2.56 (July-September) respectively was observed to be different for all the four seasons.

From the above Table 1, it has been observed that the average Relative Length of the Gut (RLG) value of 0.66 (October-December), 0.72 (JanuaryFebruary), 0.75 (March-June) and 0.70 (JulySeptember) was observed to be similar in all the four seasons. This indicates that the fish is carnivorous in nature since the RLG value is 0.7 . Moreover, RLG value of $M$. cuchia increases with the increasing length of the species and this is as shown in Fig. 2.

\section{DISCUSSION}

Since no report was available regarding food and feeding habits of $M$. cuchia in Meghalaya therefore, the present investigation provides new information regarding the gut content analysis, GastroSomatic Index (GaSl) and Relative Length of the Gut (RLG) of Mud Eel (M. cuchia) in Meghalaya. The result on the gut content analysis of $M$. cuchia 
was done and this revealed that insect larvae and zooplankton comprised the major part of their feeding items. The feeding items found in the gut content of $M$. cuchia mainly includes the Annelids (such as the Earthworms, Sludge worms, Leeches etc), Copepods, Cladocerans (namely Bosmina, Sididae etc), Rotifera, Insect larvae, Insect body parts, Sand, Mud as well as some unidentified species. Due to the presence of noticeable amount of sand and mud in gut content of this species, this suggested that $M$. cuchia is a bottom feeder.

Seasonal variation of Gastro-Somatic Index or feeding intensity of $M$. cuchia during the course of study has been presented in Fig.1. From the experiment conducted, the Gastro-Somatic Index (GaSI) value of 2.70 (October-December), 3.14 (January-February), 2.13 (March-June) and 2.56 (July-September) respectively was observed to be different for all the four seasons. It is clear from the above findings that there is an increase in feeding intensity of the species. Moreover, GaSI value of 3.14 was observed to be highest during the Pre-breeding period (January-February) and lowest GaSI value of 2.13 was observed during the Breeding period (March-June). The result of the present study is in agreement with that of the earlier workers (Faridi et al., 2016) which reported that maximum number of empty guts was observed during spawning and winter seasons in Macrognathus aculeatus.

According to (Miah et al., 2015) the fish lay their eggs from March to June each year. Lowest GaSI value of 2.13 indicates the period of low feeding intensity which coincides with the breeding period (March-June). The low feeding activity during the peak breeding season may be attributed to the completely developed gonads, permitting limited space in the abdominal cavity for intake of food. Moreover, the intensity in food intake increased following spawning and the fact that the fishes need more food for their growth. Similar observation has also been made by (Jyrwa and Bhuyan, 2016 in Neolissochilus hexagonolepis).

Further it was observed that there is a declining rate in feeding activity of females Monopterus $\mathrm{cu}$ chia from March to June which corresponds to their breeding season. Previous workers have also reported similar type of observations in different fish species (Jhingran, 1961; Desai, 1970; Bhatnagar and Karamchandani, 1970; Fatima and Khan, 1993; Mitra et al., 2006; Gandotra et al., 2007; Sarkar and Deepak, 2009; Mondal and Kaviraj, 2010; Kanwal and Pathani, 2012). Moreover, Gastro-Somatic Index (GaSI) value in females starts to rise again from July after the breeding season is over. This decrease in GaSI value occurring way ahead of the breeding season can be explained by the impact of other factors such as non availability of food items or abiotic factors like temperature and turbidity (Abbas, 2010). Full guts was found to be absent in case of females from March-June, possibly because of the development of the ovaries which occupies almost the entire abdominal cavity. According to (Desai, 1992) food and feeding behavior of fish diverge as per availability of food, depending on the ecology of the environment. Suresh et al., (2006) also found similar results while studying a closely related species, Macrognathus pancalus.

Information on Relative length of gut (RLG) in relation to their food and feeding habits in case of Glyptothorax lineatus (Nath, 1985), Fishes in Jammu Province (Nath, 1996), Tenulosa ilisha (De and Datta, 1990), Acrossocheilus hexagonolepis (Dasgupta, 1988), Labeo rohita (Dasgupta, 1995) and fresh water fishes of West Bengal (Dasgupta, 2002) is limited. According to (Al-Hussaini, 1949) the length of the gut is compensated by the average mucosal area and a short gut may be compensated by longer mucosal folds. Moreover, Das and Moitra (1956) plotted the total length of each species against the body length and found out that the ratio between the total length and the body length of the species is fairly constant. It may be easy to explain the feeding habits of a fish by mere consideration of the ratio, which is different for different species. It is evident that the ratio falls gradually from the herbivorous to carnivorous fishes thus establishing a series from the former to the latter. These can be expressed as the angle subtended by the gut length body length ratio constant for each species and it may be possible in the long run to tell the food habits of any species by merely plotting its RLG against body length (Dasgupta, 2004).

Further, it has been observed in the present study that the average Relative Length of the Gut (RLG) value of 0.66 during the spent period (OctoberDecember), RLG of 0.72 during the Pre-Breeding period (January-February), RLG value of 0.75 during the Breeding period (March-June) and RLG value of 0.70 during the Post-breeding period (July -September) was observed to be similar in all the four seasons. This indicates that the fish is carnivorous in nature since the RLG value is 0.7 . The result of the present analysis is in agreement with that of the earlier workers (Dasgupta, 2004). This is supported from the gut content analysis which is further supported by the result obtained on the food and feeding habits as well as the morphology of the alimentary canal. Moreover, it has been observed in the present analysis that as the length of the species increase, the RLG values also increases.

\section{Conclusion}

The composition of the diet was observed to be almost similar for all size groups $(20-30 \mathrm{~cm}, 31-$ $40 \mathrm{~cm}, 41-50 \mathrm{~cm}, 51-60 \mathrm{~cm}, 61-70 \mathrm{~cm}, 71-80 \mathrm{~cm}, 81-$ 
$90 \mathrm{~cm})$. This revealed the absence of any major change in food preference with age and growth. The presence of noticeable amount of sand and mud in gut content analysis also suggested that $M$. cuchia is a bottom feeder. Moreover, Relative Length of the Gut (RLG) values as well as analysis of gut content strongly suggests that this species exhibited a carnivorous mode of feeding. Earthworms, Insect larvae and Zooplanktons were found to be the most preferred food items in $M$. cuchia.

\section{ACKNOWLEDGEMENTS}

Financial support of the Department of Fisheries, Government of Meghalaya is gratefully acknowledged.

\section{REFERENCES}

1. Abbas, A. (2010). Food and feeding habits of freshwater catfish, (Bleeker) Eutropiichthys vacha. Indian Journal of Scientific Research.1 (2): 83-86.

2. Al-Hussaini, A.H. (1949). On the functional morphology of the alimentary tract of some fishes in relation to differences in their feeding habits. Quarterly Journal of Mar. Set. (2): 190-240.

3. Bhatnagar, G.K. and Karamchandani, S.J. (1970). Food and feeding habits of Labeo fimbriatus (Bloch) in river Narbada near Hoshangabad (M.P). Journal of Inland Fisheries Society of India. 2: 30-50.

4. Das, S.M. and Moitra, S.K. (1956). Studies on the food of some common fishes of Uttar Pradesh, India, Part II: On the types of fish food and the variation in the relative length of the alimentary canal with a description of the latter. Proceedings of the National Academy of Sciences, India. 26 (4): 213-223.

5. Dasgupta, M. (1988). A study on the food and feeding habits of the copper mahseer Acrossocheilus hexagonolepis (Mc Clelland). Indian Journal of Fisheries. 35:92-98.

6. Dasgupta, M. (1995). Morphometrics of the alimentary canal and filtering apparatus of Labeo rohita (Ham.) in relation to its food and feeding habits. Indian Journal of Fisheries. 42 (3): 12-15.

7. Dasgupta, M. (2002). Morphometrics of the alimentary canal of some freshwater fishes of West Bengal in relation to their food and feeding habits. Indian Journal of Fisheries. 49 (4): 461-464.

8. Dasgupta, M. (2004). Relative length of the gut of some freshwater fishes of West Bengal in relation to food and feeding habits. Indian Journal of Fisheries. 51 (3): 381-384.

9. De, N.K. and Datta, N.C. (1990). Studies on certain aspects of the morpho- histology of Indian shad, hilsa, Tenulosa ilisha (Hamilton) in relation to food and feeding habits. Indian Journal of Fisheries.37 (3):189 -198.

10.Desai, V.R. (1970). Studies on the fishery and biology of Tor tor (Ham) from river Narbada. Journal of Inland Fisheries Society of India. 2: 101-112.

11.Desai, V.R. (1992). Food of Tor tor (Hamilton) from four localities of India - A comparative analysis. Punjab Fisheries Bulletin.16 (1): 45-48.

12.Faridi, A.A. Rizvi, M.M.A. and Serajuddin, M. (2016). Food and feeding habits of peacock eel, Macrognathus aculeatus (Bloch, 1786) from Eastern Uttar
Pradesh, India. International journal of fisheries and aquatic studies. 4 (4): 130-134.

13.Fatima, M. and Khan, A.A. (1993). Cyclic changes in the gonads of Rhingomugil corsula (Ham) from river Yamuna India. Asian Fisheries Science Journal.6:2329

14.Gandotra, R. Ahmed, S. and Shanker, R. (2007). Food and feeding habit of Barilius vagra (Hamilton) a minor carp, in different age groups from Jhajhar stream, Jammu (J \& K). Aquaculture.8 (1): 1-11.

15.Jamir, N.S. and Lal, P. (2005). Ethno-zoological practices among Naga tribes. Indian Journal of Traditional Knowledge. 4 (1): 100-104.

16.Jhingran, A.G. (1961). Studies on the maturity and fecundity of the Gangetic unchovy, Setipinna phasa (Ham). Indian Journal of Fisheries. 8: 291-311.

17.Joadder, A.R. and Hossain, M.D. (2008). Convenient Pattern of Food and Feeding Habit of Liza parsia (Hamilton) (Mugiliformes: Mugilidae). Journal of Fisheries International. 3 (3): 48 -51.

18.Jyrwa, L.B. and Bhuyan, R.N. (2016). Study on the food and feeding habits of the Chocolate Mahseer (Neolissochilus hexagonolepis) from Meghalaya, India. Indian Journal of Scientific Research. 7(1):2326

19.Kakati, L.N. Bendong, A.O. and Doulo, V. (2006). Indigenous knowledge of zoo-therapeutic use of vertebrate origin by the Ao tribe of Nagaland. Journal of Human Ecology. 19 (3): 163-167.

20.Kanwal, B.P.S. and Pathani, S.S. (2012). Food and feeding habits of a hill stream fish, Garra lamta (Hamilton-Buchanan) in some tributaries of Suyal River, Kumaun Himalaya, Uttarakhand (India). International Journal of Food and Nutrition Science.1 (2): 16-22.

21.Manon, M.R. and Hossain, M.D. (2011). Food and Feeding Habit of Cyprinus carpio var. specularis. Journal of Science Foundation. (1\&2): 163-181.

22.Menon, A.G.K. (1999). Check list - fresh water fishes of India. Records of the Zoological Survey of India, Occasional Paper No. 175.

23.Miah, M.F. Ali, H. Zannath, E. Shuvra, T.M. Naser, M.N. and Ahmed, M.K. (2015). Breeding Biology and Induced Breeding Status of Freshwater Mud Eel (Monopterus cuchia). International Journal of Bioengineering and life sciences. 9 (6): 680-684.

24.Mirza, M.R. and Alam, M.K. (2002). A checklist of the fishes of the Punjab, Pakistan, Records of the Zoological Survey of Pakistan. 14: 31-35.

25.Mitra, K. Suresh, V.R. Vinci, G.K. and Mazumdar, N.N. (2006). Food habits of the soft-fin barb Puntius sophore (Hamilton-Buch.) in a floodplain wetland, West Bengal. Journal of Inland Fisheries Society of India. 38 (2): 73-76.

26.Mondal, D.K. and Kaviraj, A. (2010). Feeding and reproductive biology of Indian shad Gudusia chapra in two floodplain lakes of India. Electronic Journal of Biology. 6 (4): 98-102.

27.Munshi, J.S.D. Roy, P.K. and Nasar, S.S.T. (1989). Oxygen uptake capacity of larval respiratory organs of air-breathing swamp mud eel, Monopterus cuchia (Hamilton): A morphometric study. Proceedings of the Indian National Science Academy B55, 5 \& 6: 309-316.

28.Narejo, N.T. Rahmatullah, S.M. and Rashid, M.M. (2003). Reproductive biology of air breathing freshwater mud eel, Monopterus cuchia (Hamilton) from 
Kurbah, B. M. and Bhuyan, R.N. / J. Appl. \& Nat. Sci. 10 (4): 1187 - 1191 (2018)

Bangladesh. Indian Journal of Fisheries. 50(3):395399

29.Nath, S. (1985). On the food, feeding habits and alimentary canal of Glyptothorax lineatus (Day) (Siluriformes; Sisoridae) a torrential stream Teleost from Poonch Valley (Jammu and Kashmir State). Matsya. 2: 89-92.

30.Nath, S. (1996). Studies on the bioecology of fishes of Jammu Province (Jammu and Kashmir State) India, Part IV: Food, feeding types and morphological Adaptations of the alimentary Canal of some fishes of Jammu Province. In: Recent Advances in Fish Ecology, Limnology and Eco-conservation, Daya Publishing House, Delhi.

31.Nikolsky, G.V. (1963). Ecology of Fishes. Academic Press London. 352.

32.Quddus, M.M.A. Banerjee, A.K. Parveen, F. Ara, R. and Costa, M.P. (2000). Development of social fish- ery technology using small indigenous fishers of Bangladesh. Dhaka University Journal of Biological Sciences. 9 (2): 131-138.

33.Sarkar, U.K. and Deepak, P.K. (2009). The diet of clown knife fish Chitala chitala (Hamilton-Buchanan) an endangered Notopterid from different wild population (India). Electronic Journal of Ichthyology. 1:11-20

34.Suresh, V.R. Biswas, B.K. Vinci, G.K. and Mukherjee, A. (2006). Biology and fishery of barred spiny eel, Macrognathus pancalus (Hamilton). Acta Ichthyologica et Piscatoria. 36: 31-37.

35.Talwar, P. K. and Jhingran, V.G. (1991). Inland Fishes of India and adjacent countries. Oxford-IBH Publishing Co. Pvt. Ltd. New Delhi. Vol. 1 and 2, p.1147

36.Zhou, R. Cheng, H. Zhang, Q. Guo, Y. Richard, R.C. and Terrence, R.T. (2002). SRY-related genes in the genome of the rice field eel (Monopterus albus). Genetics Selection Evolution. 34(1):129-137 